\title{
Modelling soil water content variations under drought stress on soil column cropped with winter wheat
}

\author{
Szilveszter Csorba ${ }^{1}$, Andrea Raveloson $^{2}$, Eszter Tóth ${ }^{3}$, Viliam Nagy $^{4}$, Csilla Farkas $^{5 *}$ \\ ${ }^{1}$ Szent István University, Páter Károly u. 1, Gödöllő 2100, Hungary. \\ ${ }^{2}$ Eötvös Loránd University, Pázmány Péter sétány 1/A, Budapest 1117, Hungary. \\ ${ }^{3}$ Institute for Soil Sciences and Agricultural Chemistry, Centre for Agricultural Research, Hungarian Academy of Sciences, Herman O. u. 15, \\ Budapest 1022, Hungary. \\ ${ }^{4}$ Institute of Hydrology, Slovak Academy of Sciences, Racianska 75, 81302 Bratislava, Slovak Republic. \\ ${ }^{5}$ Bioforsk, Norwegian Institute for Agricultural and Environmental Research, Fr. A. Dahlsvei 20, Ås 1430, Norway. \\ * Corresponding author. Tel.: +47 9481-4727. E-mail: csilla.farkas@bioforsk.no
}

\begin{abstract}
Mathematical models are effective tools for evaluating the impact of predicted climate change on agricultural production, but it is difficult to test their applicability to future weather conditions. We applied the SWAP model to assess its applicability to climate conditions, differing from those, for which the model was developed. We used a database obtained from a winter wheat drought stress experiment. Winter wheat was grown in six soil columns, three having optimal water supply (NS), while three were kept under drought-stressed conditions (S). The SWAP model was successfully calibrated against measured values of potential evapotranspiration (PET), potential evaporation (PE) and total amount of water (TSW) in the soil columns. The Nash-Sutcliffe model efficiency coefficient (N-S) for TWS for the stressed columns was 0.92 . For the NS treatment, we applied temporally variable soil hydraulic properties because of soil consolidation caused by regular irrigation. This approach improved the N-S values for the wetting-drying cycle from -1.77 to 0.54 . We concluded that the model could be used for assessing the effects of climate change on soil water regime. Our results indicate that soil water balance studies should put more focus on the time variability of structuredependent soil properties.
\end{abstract}

Keywords: Climatic room; SWAP model; Soil water balance elements; Drought stress; Temporal variability of soil properties.

\section{INTRODUCTION}

Wheat is the most important cereal around the world ensuring the food demand of the growing population. At present climate conditions, drought stress and extreme weather conditions are the major constraints limiting the biomass production of cereals in most areas of the Carpathian Basin (Cseuz et al., 2002; Hermann et al., 2006; Várallyay, 2005) and in many other places around the world (Fendeková and Fendek, 2012; Josa et al., 2013; Querrie et al., 1999; Rosenzweig et al., 2001). For the temperate regions, all the models predict decrease in wheat yields even in case of small increase in average air temperature, if no adaptation strategies are implemented (IPCC, 2014; Maracchi et al., 2005).

Besides other adaptation measures (i.e. irrigation, changes in management strategies), selection and development of new drought stress tolerant wheat genotypes could help in reducing yield damages due to temperature increase and drought (Végh, 2013). Exact calculation of crop water demand and consumption under stressed conditions, however, remains a challenging task.

Drought and heat tolerance of different wheat genotypes can be determined in stress diagnostic systems of different types. In glasshouse stress diagnostic systems (Djilianov et al., 2005), a large number of pots are used. Thus, precise and continuous monitoring of water balance elements would be very expensive and time-consuming. On the other hand, results obtained from field stress diagnosis systems (Pant et al., 1998) are difficult to reproduce due to uncontrolled weather conditions.

Mathematical models, describing the physical laws valid in the soil-plant-atmosphere system are promising tools for evalu- ating the impact of predicted climate change on crop water use efficiency. However, these models often incorporate semiempirical functions and relationships, so their validity for conditions that differ from those they have been developed for should be tested.

In this study, we used data obtained from a detailed soil water balance study carried out in a climate room (Lukács et al., 2008) to assess the applicability of the SWAP (Soil, Water, Atmosphere and Plant) mathematical model (van Dam, 2000; van Dam et al., 2008) to climatic conditions that significantly differ from those that the model has been developed and tested for. The hypothesis of this study was that if we successfully apply a model for meteorological conditions, for which the built-in physical relationships are still valid (e.g. the changes in climatic conditions are not that extreme so that the existing physical laws would become invalid, which is very likely the case for the expected climate change conditions), than pretested and calibrated (for certain crops and soils) mathematical models could be used to overcome the experimental limitations and to quantify the water balance elements under changing climate.

Soil tillage, rainfall events and crop growth can cause strong seasonal variation of soil structure and the related soil hydraulic properties. Kodešová et al. (2011) reported that soil structure of the topsoil of a Haplic Luvisol was very sensitive to rainfall events. Jirků et al. (2013) found highly variable soil aggregate stability and soil hydraulic properties in three different soil types. Temporal variability of the examined soil properties was depended on plant growth, rainfall compaction and tillage. Temporal changes in soil properties can have significant effect on soil water regime (Farkas et al., 2000). Most of the 
mathematical models simulating soil water regime, however, do not account for temporal changes in soil hydraulic properties (Farkas et al., 2000), even though these properties are strongly effected by climate conditions and soil management (Korsunskaia and Farkas, 2004; Zhou et al. 2008). Temporal variations in soil properties are usually neglected, for two main reasons: i) there are very little data and information on the seasonal variability of soil hydraulic properties that could be used for developing and testing new model applications and ii) it is rather complicated to account for these temporal changes (represented by discrete measured values) in numerical schemes requiring continuous information.

In this study our aims were i) to evaluate the applicability of the SWAP model to climatic conditions outside the range used to develop the model; ii) to compare the modelling results with those of a detailed soil column water balance study as part of a drought stress tolerance wheat experiment and iii) to evaluate the effect of temporal changes in soil physical and hydraulic properties on the model's performance.

\section{MATERIALS AND METHODS}

\section{Laboratory experimental set up}

For mathematical modelling of the soil water balance elements under non-regular conditions we used data, obtained from the stress diagnosis set up introduced by Lukács et al. (2008). The system consisted of eight soil columns with winter wheat, placed in identical plexiglass boxes with an area of $0.15 \times 0.15 \mathrm{~m}^{2}$ (Fig. 1). The boxes were filled with $8.496 \mathrm{~kg}$ of air-dried soil until $0.32 \mathrm{~m}$ height, so that the total soil volume (V) was $7.2 \times 10^{-3} \mathrm{~m}^{3}$ to achieve equal dry soil bulk density of $1.18 \times 10^{3} \mathrm{~kg} \mathrm{~m}^{-3}$.

The soil type was defined as Calcic Chernozem (WRB, 2006) developed on clayey loam. The soil columns were constructed using soil material taken from the field from two different soil layers: the upper $0.2 \mathrm{~m}$ and 0.2 to $0.32 \mathrm{~m}$ layers of the $0.32 \mathrm{~m}$ height column were filled with the topsoil (A layer) and subsoil (B layer), respectively. The soil columns were pla- ced in a climatic room under controlled environment as temperature, humidity, wind speed and light conditions. The air temperature and the relative humidity of the climatic room were monitored every 30 minutes with a sensor placed at the height of the plants. The air temperature varied between $19.8^{\circ} \mathrm{C}$ and $24.5^{\circ} \mathrm{C}$, the relative humidity was kept constant at $83 \%$. Potential evapotranspiration was determined by the pan evaporation method (Szász, 1997): a pan with a large surface was filled with water and placed next to the soil columns, and its weight loss was regularly monitored. The potential evapotranspiration rate was found to be constant and equal to $0.25410^{-3} \mathrm{~m}^{3}$ day $^{-1}$ (Lukács et al., 2008).

"Mv Emese" wheat (Triticum aestivum L.) genotypes (Gáspár et al., 2005) that are considered to be water stress tolerant, were planted in six boxes. The initial soil water content was set at field capacity $\left(0.38 \mathrm{~m}^{3} \mathrm{~m}^{-3}\right)$ and to soil moisture content of $0.20 \mathrm{~m}^{3} \mathrm{~m}^{-3}$ in the four NS and four S pots, respectively. Two out of the eight soil columns were left without plants. Three out of the six plants got the optimum amount of water (non-stressed conditions, NS), ensuring soil water content $(\Theta)$ between $60 \%$ and $100 \%$ of the field capacity, $\Theta_{\mathrm{FC}}$. The drought-stressed (stressed, S) plants were kept at the soil water content around $20 \%$ of the $\Theta_{\mathrm{FC}}$. One of the bare pots (without wheat) was irrigated on the base of the $\mathrm{S}$, while the other one was watered according to the NS irrigation strategy to monitor evaporation from bare soil surface. The total amount of water in each column was monitored by weighting the soil columns two times a week. The mass of water in each column was calculated as the difference between the actual column weight and its weight in air-dry conditions $(8.496 \mathrm{~kg})$, minus the weight of the plexiglass box. The gravimetric soil water content $\left(\Theta_{g}\right)$ was calculated from the mass of water and that of air-dry soil. Further, the volumetric soil water content was determined by multiplying the gravimetric soil water content by the soil bulk density $\left(1.18 \times 10^{3} \mathrm{~kg} \mathrm{~m}^{-3}\right)$.

Data on temporal changes in the water content of the pots with bare soil were used to calculate the evaporation from the soil surface for NS and S columns as described in Lukács et al. (2008).

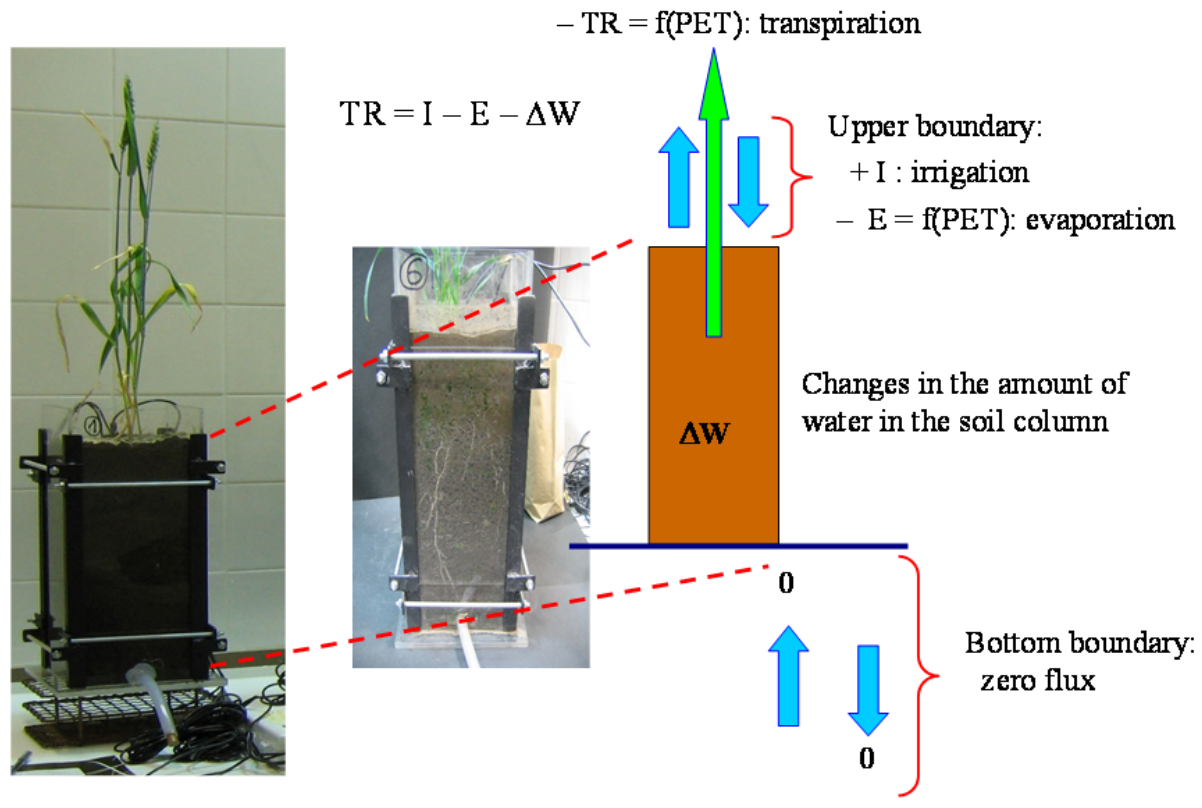

Fig. 1. Schematic diagram of the experimental set up. TR, E, PET, I stand for transpiration, evaporation, potential evapotranspiration and irrigation, respectively. 
Development of the winter wheat plants was also monitored. The experimental set up the irrigation and the monitoring strategy are described in details in Lukács et al. (2008).

\section{Application of the SWAP model for calculating soil water balance elements}

We applied the SWAP (version 2.2; van Dam, 2000) mathematical model to calculate the soil water balance elements of the soil columns, using the database obtained from 75-day long measurements in the stress diagnostic system. Farkas and Hagyó (2010) reported that the SWAP model is suitable for predicting the soil water regime and the soil water balance elements under Hungarian circumstances. Indeed, in our case the meteorological conditions differed strongly from those, measured in the field, therefore our study also concerned the applicability of the model for climatic room conditions.

The SWAP model is a mathematical model that calculates soil water balance elements (evaporation, transpiration, deep percolation, surface runoff, interception etc.), integrated at daily time step. It employs the Richards' equation (Richards, 1931), which is a non-linear partial differential equation representing the movement of water in unsaturated soils. It has been developed by merging Darcy's law with the continuity equation and by adding a sink term to account for the root water uptake (Feddes et al., 1978). The soil hydraulic functions are described by the analytical expressions of van Genuchten (1980) and Mualem (1976) from measured values. Potential evapotranspiration is calculated using the Penman-Monteith method (Monteith, 1981). Potential evaporation and its reduction due to soil cover are calculated according to Boesten and Stroosnijder (1986). Root water extraction at various depths of the root zone is calculated from potential transpiration, root length density, and possible reductions due to wet, dry or saline conditions (van Dam 2000). At the lower boundary of the soil profile, different kind of boundary conditions can be specified, including free drainage or zero flux at the bottom of the profile, pressure head of bottom compartment or given groundwater level (van Dam, 2000). The main model input data requirements are (i) soil profile data; (ii) weather data, and iii) vegetation data.

For input files containing meteorological driving variables we used the records of the air temperature and humidity sensors, the pre-set climatic room characteristics (light intensity, wind speed) and the measured PET values. Water amounts, used for irrigation in the S and NS treatments were introduced in the model.

Soil input data consisted of the Van Genuchten - Mualem model (VG) parameters (Table 1) fitted to the measured soil water retention data using the RETC (Retention Curve Model for Soil Water Models) software (van Genuchten et al., 1991) with the Mualem constrain $(\mathrm{m}=1-1 / \mathrm{n}$, Mualem, 1976) and assuming -1 for the exponent $\mathrm{L}$ of the hydraulic conductivity function. Saturated hydraulic conductivity $\left(\mathrm{K}_{\mathrm{s}}\right)$ and the soil water retention data were determined from undisturbed soil samples. The latter were measured at matric potentials of -0.1 , $-0.25,-1.0,-3.2,-10,-20,-50,-251$ and $-1585 \mathrm{kPa}$. We found good agreement between the measured and fitted soil water retention functions: the coefficient of determination $\left(\mathrm{R}^{2}\right)$ were above 0.98 for both the soil layers, while the slope of the regression lines was 1.011 and 1.037 for the upper and lower soil layers, respectively.

During the experiment, soil consolidation was observed especially in the non-stressed pots most probably because of regular irrigation and natural consolidation. We monitored this pro- cess as it caused changes in soil bulk density and, consequently, in soil hydrological functions. Further, we separated the SWAP simulations for the NS treatment into two periods. We used the original parameters of the Van Genuchten - Mualem model (van Genuchten, 1980) to represent the soil hydraulic functions for the first (38-day long) period that corresponded to a drying cycle. For the second period, consisting of wetting-drying cycles we used the modified Van-Genuchten functions (SW, Eq. 1 and 2), suggested by Sobczuk and Walczak (1996).

$\Theta=\left(\frac{1}{\rho}-\frac{1}{\rho_{0}}\right)\left[1+(\alpha \Psi)^{n}\right]^{\frac{1}{n}-1}$

considering

$n=\frac{\rho_{0}-\rho C}{2}$

where: $\Theta$ - calculated soil water content $(\mathrm{kg} / \mathrm{kg}), \rho$ - bulk density of the soil sample $\left(10^{-3} \mathrm{~kg} / \mathrm{m}^{3}\right), \rho_{0}$ - density of the solid phase of the soil $\left(10^{-3} \mathrm{~kg} / \mathrm{m}^{3}\right), \Psi$ - soil water potential $\left(10^{-2} \mathrm{~m}\right.$ of $\left.\mathrm{H}_{2} \mathrm{O}\right), \alpha$ - fitting parameter $\left(10^{-2} 1 / \mathrm{m}\right), C$ - fitting parameter $\left(10^{-3} \mathrm{~m}^{3} / \mathrm{kg}\right)$

This method was originally developed to estimate the soil water retention curves for soils with variable soil bulk density. The soil-specific fitting parameters $C$ and $\alpha$ were available for the different soil layers of the study site (e.g. site where the soil samples were taken for the experiment) from Korsunskaia and Farkas (2004), which allowed estimation of changes in the soil water retention curve due to changes in soil bulk density. Accordingly, the reduced soil bulk density was calculated from the average level of settlement, observed in the three NS columns, and the corresponding Van Genuchten parameters were derived, using the Sobchuk-Walczak (SW) site-specific coefficients, determined by Korsunskaia and Farkas (2004).

Input data on crop parameters, as crop height and LAI were measured directly, while the maximum rooting depth was observed through the transparent walls of the boxes (Csorba, 2007). We selected the simple crop routine of the SWAP model for simulating the development and water uptake of the winter wheat. The crop routine was parameterised, using observed data on LAI, crop height and maximal rooting depth as a function of crop development stage.

For all the soil layers, $0.38 \mathrm{~m}^{3} \mathrm{~m}^{-3}$ and $0.20 \mathrm{~m}^{3} \mathrm{~m}^{-3}$ water content was set as initial conditions for the NS and N columns, respectively. The upper boundary conditions as infiltration and evaporation were calculated by the model from the meteorological input data. No water movement occurred from the bottom of the columns through the installed plastic tubes (Fig. 1), as the soil column retained all the irrigation water within the pore system, most probably due to the clayey loam texture. Therefore, zero flux was set as alower boundary condition.

\section{Statistical analyses}

The SWAP model was calibrated by tuning on model parameters to minimise the difference between the measured and simulated values of potential evapotranspiration (PET), potential evaporation (PE) and total amount of water (TSW) in the soil column. All the meteorological and soil input data were similar for the three replicates of the S and NS treatments, and the model was insensitive against the observed small differ- 
ences in crop parameters. Therefore, we did not perform calibrations separately for all the six soil columns, but calculated the average measured TSW values for the three replicates and used them to evaluate the model performance statistics.

We used different statistics to evaluate the goodness of fit of simulated values to observations. Simulated and observed PET, PE, PTR and TSW values were compared by Pearson's Correlation (coefficient of determination - $\mathrm{R}^{2}$ ), by the Nash-Sutcliffe model efficiency coefficient (N-S, Nash and Sutcliffe, 1970) and the volume differences (PBIAS), (Moriasi et al., 2007).

We compared the obtained goodness-of-fit statistics with those, reported by Moriasi et al. (2007) to assess the applicability of the SWAP model to conditions, strongly differing from those, experienced in the field.

\section{RESULTS AND DISCUSSION}

\section{Temporal variability of soil hydraulic properties}

The height of the non-stressed columns decreased in average by $0.022 \mathrm{~m}$, causing a $4.95 \times 10^{-3} \mathrm{~m}^{3}$ decrease in the volume of the soil columns. Consequently, soil bulk density increased from $1.18 \times 10^{3} \mathrm{~kg} \mathrm{~m}^{-3}$ to $1.27 \times 10^{3} \mathrm{~kg} \mathrm{~m}^{-3}$.

Figure 2 demonstrates the original water retention curves, fitted to the measured data using the VG model, and their changes, estimated with the Sobchuk-Walczak method (SW) assuming $0.09 \mathrm{~kg} \mathrm{~m}^{-3}$ increase in soil bulk density. The VG and SW parameters are given in Table 1 .

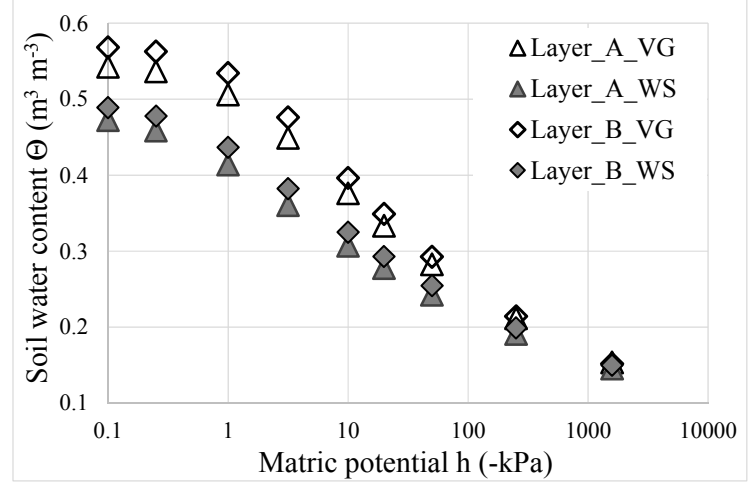

Fig. 2. Initial (represented by the van Genuchten - VG-model) and changed due to soil consolidation (described with the SobchukWalczak - SW-model) soil water retention curves of the two soil layers (A and B) in the non-stressed experimental columns.

As it was expected, soil compaction resulted in $0.08 \mathrm{~m}^{3} \mathrm{~m}^{-3}$ reduction in total porosity (and saturated soil water content) for both the soil layers (Table 1). According to our estimations, compaction mostly effected soil water retention curves in the high matric potential range (soil water content range between saturation and field capacity), which is in good agreement with other findings. Głab (2014) reported that in a tillage experiment on a sandy loam soil compaction resulted in higher bulk density and lower total porosity values and significantly influenced the soil water retention characteristics in the high matric potential range due to decrease in volume of large pores. Similar conclusions were drawn by Kutilek et al. (2006) and Zhang et al. (2006).

\section{SWAP model efficiency to predict evapotranspiration characteristics}

Cumulative values of potential evapotranspiration (PET), potential evaporation from the bare soil surface $(\mathrm{PE})$ and potential transpiration (PTR) for the S and NS treatments, and the corresponding model calibration statistics are given in Table 2 . We expected to obtain good model fit for PET, as the measured PET values were directly introduced in the input file for driving meteorological variables. Simulated values of potential and actual evaporation from bare soil surface were calibrated to the measured values by fine-tuning the evaporation coefficient (B1) of Boesten and Stroosnijder (1986). The calibrated values of B1 were 0.3 and 0.6 for the S and NS treatments, respectively.

The N-S and PBIAS values for PET, PE and PTR were compared with the general model performance ratings, reported by Moriasi et al. (2007) for monthly time step. According to the N$S$ values, the performance rating of the PET and PE calibration falls in the ,satisfactory" $(0.50<\mathrm{N}-\mathrm{S} \leq 0.65)$, while that of the PTR falls in the ,very good" $(0.75<\mathrm{N}-\mathrm{S} \leq 1.00)$ model performance category. As PBIAS values are smaller than $10 \%$ for all the three water balance elements and for both the treatments, the PBIAS-based the calibration ratings belong to the best, socalled ,very good" (PBIAS $\leq \pm 10 \%$ ) performance rating category. When comparing the model calibration results of five different (profile and catchment scale) models for runoff, Deelstra et al. (2010) found that ,model performances, in general, improved when integrating the results over longer time periods, indicating, that the daily runoff dynamics were not simulated satisfactorily, while the weekly and monthly runoff was simulated quite well". Based on these findings and considering that the performance ratings of our daily time step calibration were at least satisfactory when using evaluation criteria, developed on a monthly basis, we can conclude that the SWAP model could successfully simulate the PET, PE and PTR dynamics in a climatic room environment. Consequently, the model provided precise upper boundary conditions for detailed water balance studies.

Although many studies are focused on testing the SWAP model against measured data on soil water balance elements (Bennett et al., 2013; Ma et al., 2011), they are mostly based on

Table 1. Soil hydraulic parameters, used in the model simulations.

\begin{tabular}{|c|c|c|c|c|c|c|c|c|c|}
\hline \multirow{3}{*}{ Soil layer } & \multirow{3}{*}{$\begin{array}{c}\text { Depth } \\
\text { m }\end{array}$} & \multicolumn{5}{|c|}{ Van Genuchten model parameters } & \multicolumn{3}{|c|}{ Sobchuk-Walczak parameters } \\
\hline & & $\mathrm{WC}_{\mathrm{R}}$ & $\mathrm{WC}_{\mathrm{S}}$ & alpha & $n$ & $K_{s}$ & $\mathrm{WC}_{\mathrm{s}}$ & alpha & $C$ \\
\hline & & \multicolumn{2}{|c|}{$\mathrm{m}^{3} \mathrm{~m}^{-3}$} & $10^{-2} \mathrm{~m}^{-1}$ & - & $m$ day $^{-1}$ & $\mathrm{~m}^{3} \mathrm{~m}^{-3}$ & $10^{-2} \mathrm{~m}^{-1}$ & $10^{-3} \mathrm{~m}^{3} \mathrm{~kg}^{-1}$ \\
\hline A & $0.00-0.20$ & 1.0 & 0.55 & 0.067 & 1.1968 & 0.12 & 0.47 & 0.2019 & 0.1207 \\
\hline B & $0.20-0.32$ & 1.1 & 0.57 & 0.055 & 1.2114 & 0.12 & 0.49 & 0.1505 & 0.1525 \\
\hline
\end{tabular}

Where $\mathrm{WC}_{\mathrm{R}}$ and $\mathrm{WC}_{\mathrm{S}}$ are the residual and saturated water content of the soil, respectively, expressed in $\mathrm{v} \%$; alpha and $n$ are the parameters of the van Genuchten model and $K_{s}$ is the soil saturated hydraulic conductivity. 
Table 2. Water balance elements $\left(10^{-2} \mathrm{~m}\right.$, average from three replicates) cumulated for the first 68 -day period of measurements and the corresponding statistics for model simulations.

\begin{tabular}{|c|c|c|c|c|c|c|c|c|c|c|}
\hline & \multicolumn{4}{|c|}{$\begin{array}{l}\text { Water balance elements } \\
\qquad\left(10^{-2} \mathrm{~m}\right)\end{array}$} & \multicolumn{6}{|c|}{ Model simulation statistics } \\
\hline & \multicolumn{2}{|c|}{ NS } & \multicolumn{2}{|c|}{$\mathrm{S}$} & \multicolumn{2}{|c|}{$\mathrm{R}^{2}$} & \multicolumn{2}{|c|}{ N-S } & \multicolumn{2}{|c|}{ PBIAS (\%) } \\
\hline & Obs & Mod & Obs & Mod & NS & $\mathrm{S}$ & NS & $\mathrm{S}$ & NS & $\mathrm{S}$ \\
\hline PET & 76.8 & 76.5 & 76.8 & 76.3 & 0.85 & 0.87 & 0.53 & 0.61 & -0.4 & -0.7 \\
\hline PE & 22.0 & 20.5 & 22.2 & 22.2 & 0.94 & 0.94 & 0.64 & 0.40 & -6.8 & 0.9 \\
\hline PTR=PET-PE & 54.8 & 56.0 & 54.8 & 54.1 & 0.99 & 0.99 & 0.93 & 0.89 & -2.2 & -1.3 \\
\hline
\end{tabular}

Where PET, PE and PTR are the potential amounts of evapotranspiration, evaporation and transpiration, respectively. NS and S stand for columns with no water stressed and water stressed wheat plants. $\mathrm{R}^{2}, \mathrm{~N}-\mathrm{S}$ and PBIAS are the coefficient of determination, the Nash-Sutcliffe model efficiency coefficient and the percent bias, respectively. Obs and Mod refer to observed and modelled values.

field-measured data. Soldevilla-Martinez et al. (2014) compared the performance of the DSSAT model, which uses the simple "tipping bucket" approach for describing soil water balance with that of the WAVE model that - similarly to SWAP - integrates Richards' equation. They carried out their study in a lysimeter experiment and found that both models performed well simulating the soil water balance components for the calibration period. Indeed, the lysimeters were installed in the field under natural weather conditions. Trakal et al. (2013) validated the Hydrus-2D model for simulating the $\mathrm{Cd}, \mathrm{Cu}, \mathrm{Pb}$ and $\mathrm{Zn}$ transport within a soil column in a greenhouse under controlled conditions. They found excellent and acceptable agreement between the measured and modelled soil water content data in the control (without vegetation) and vegetation (willow) scenarios, respectively. Their results are in good agreement with our findings indicating that soil water balance models based on Richards' equation are capable to simulate the upper bottom boundary conditions and the soil water regime under controlled, non-natural weather conditions.

\section{SWAP model performance in estimating soil water content}

Figures 3 and 4 demonstrate the measured (Obs) and modelled (Mod) values of the total amount of water (TSW) in the soil column for the drought-stressed (S) and non-stressed (NS) treatments, respectively. The discrete points (Obs_NS1, Obs_NS2, OBS_NS3, Obs_S1, Obs_S2 and Obs_S3) represent the three replicates of the non-stressed and stressed treatments. Statistical evaluation of the model calibration, calculated using the average values of the three replicates for each treatment is given in Table 3 .

Besides, we performed statistical evaluation for each of the three replicates of the NS and S treatment. For the S treatments, the average N-S and PBIAS values were 0.90 and 0.92 , and varied among the replicates from 0.82 to $0.92(\mathrm{~N}-\mathrm{S})$ and from 1.3 to $0.9 \%(\mathrm{~S})$, respectively, all falling into "very good" model performance rating category (Moriasi et al., 2007). These results indicate that the calibration of the SWAP model against the TSW values measured in the stressed treatments was successful. Indeed, the difference between the measured and simulated TSW values increased after the few irrigation events (Fig. 3). We assume that soil consolidation (and decrease in soil volume) observed during the experiment could be the main reason for that, as it causes changes in soil hydraulic properties. The SWAP model runs with stationary soil hydraulic parameters; therefore, it cannot take into consideration the temporal variability of soil hydraulic properties. As the calibration results were still very good for the $\mathrm{S}$ treatment, differences in measured and simulated TSW values could be neglected.

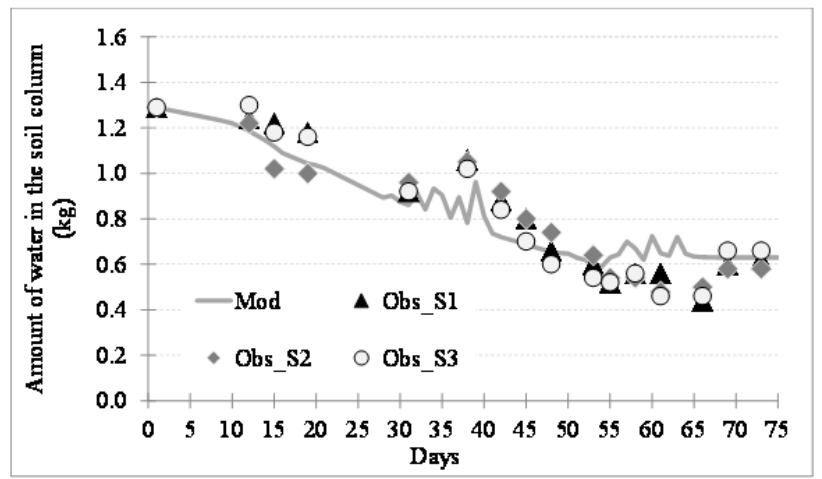

Fig. 3. Simulated (Mod) and observed (Obs) values of total soil water in the soil columns with drought-stressed winter wheat.

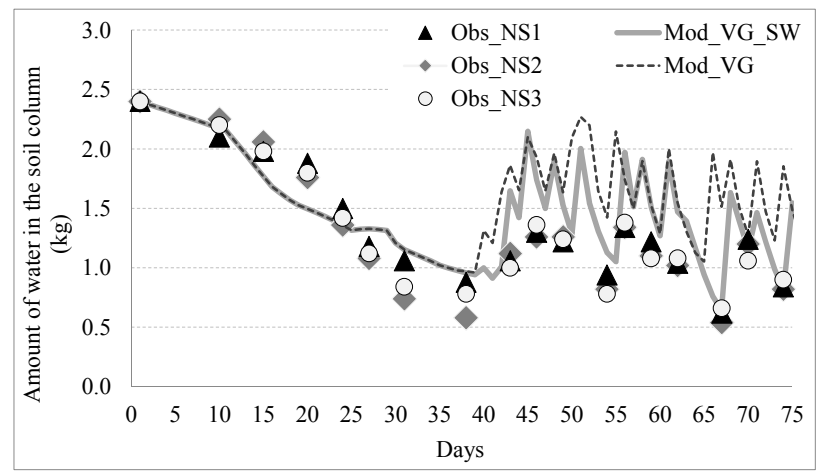

Fig. 4. Simulated (Mod) and observed (Obs) values of total soil water in the soil columns with winter wheat receiving optimum water supply. VG and VG_SW refer to simulation results with temporally stable (using Van Genuchten parameters) and temporally variable (using Van Genuchten and Sobczuk - Walczak parameters) soil hydraulic properties, respectively.

Soil consolidation was more visible in the soil columns with winter wheat receiving optimal water supply (NS treatments). While calibrating the SWAP model to the NS treatments, it became clear that the model couldn't fit the observed TSW data for the whole measurement period, if using the same VG parameters. The simulated TSW values fitted well the first 38-day period, with $\mathrm{R}^{2}, \mathrm{~N}-\mathrm{S}$ and PBIAS values of $0.90,0.82$ and $0.9 \%$, respectively. This period corresponded to a drying cycle. The model overestimated the soil water content for the rest of the measurement period, characterised by wetting - drying cycles. The $\mathrm{R}^{2}, \mathrm{~N}-\mathrm{S}$ and PBIAS statistics were, in this case $0.16,-1.77$ and $8.0 \%$, correspondingly, indicating rather poor model performance. 
Table 3. Model calibration statistics for the averaged for the replicates total amounts of water in the soil columns for the $\mathrm{S}$ and NS treatments.

\begin{tabular}{|c|c|c|c|c|c|c|}
\hline \multirow[b]{2}{*}{ Model } & \multirow{2}{*}{$\begin{array}{c}\begin{array}{c}\text { Drying } \\
\text { period }\end{array} \\
\mathrm{VG}\end{array}$} & \multicolumn{2}{|c|}{ Wetting-drying cycle } & \multicolumn{3}{|c|}{ Total period } \\
\hline & & VG & SW & VG & VG & VG-SW \\
\hline Treatment & NS & NS & NS & $\mathrm{S}$ & NS & NS \\
\hline $\mathrm{R}^{2}$ & 0.90 & 0.16 & 0.74 & 0.90 & 0.63 & 0.88 \\
\hline $\mathrm{N}-\mathrm{S}$ & 0.82 & -1.77 & 0.54 & 0.92 & 0.61 & 0.87 \\
\hline PBIAS & 0.9 & 8.0 & 5.4 & 0.8 & 4.1 & 2.9 \\
\hline
\end{tabular}

Where NS and S are the columns with non-stressed and water stressed wheat plants; VG and SW correspond to simulation runs with Van-Genuchten and Sobchuk-Walczak soil hydraulic parameters. $\mathrm{R}^{2}, \mathrm{~N}-\mathrm{S}$ and PBIAS are the coefficient of determination, the Nash-Sutcliffe model efficiency coefficient and the percent bias, respectively.

We assume, that the detected changes in soil bulk density and the corresponding changes in the soil hydraulic properties caused failing in the model simulations for the wetting - drying period. Therefore, we separated the simulations into two time periods (drying and wetting-drying cycles) and modelled the TSW dynamics separately for each of them. Soil hydraulic properties for the second period were estimated by Korsunskaia and Farkas (2004) using SW parameters according to Sobczuk and Walczak (1996), as described before.

Statistical evaluation of the simulation results for the NS treatment (Table 3 ) showed "very good" performance rating for the first (drying) period in case of both, N-S and PBIAS, and also for the second (wetting-drying) period with respect to PBIAS values. The N-S values for the second period fall in the "good" and "satisfactory" range.

Our results are in good agreement with those, obtained by Farkas et al., (2000) and Schwen et al. (2011). Schwen et al. (2011) focused on improving soil water simulations for tilled soils by accounting for temporal changes of near-surface soil hydraulic properties in the Richards' 1D equation. They concluded that the performance of the simulation could be improved significantly using time-variable hydraulic parameters, regardless of the tillage system in focus.

Mubarak et al. (2009) applied the Hydrus-2D code to study ,the effect of temporal variability in the hydraulic properties of a loamy soil during a maize cropping cycle on water transfer under daily drip irrigation". Contradictoriliy to our results they found, that even though there were observed changes in soil hydraulic properties during the experiment, both sets of soil hydraulic functions corresponding to the periods before and after the irrigation could accurately reproduce measured soil water content profiles.

We assume, that the soil type, the level of changes in soil properties and the aim of the study identify, whether constant or time-dependent soil hydraulic propoerties should be used for water balance modelling.

\section{CONCLUSIONS}

We tested the applicability of the SWAP mathematical model for climatic conditions, strongly differing from those, experienced in a field, by applying it to a data set, measured in a climatic room experiment. We concluded, that the model could satisfactorily describe the hydrological processes in the soilplant-atmosphere system under climatic conditions falling outside the range the model was developed for. Therefore, it can be used for assessing the effects of predicted climate change on soil water regime and corresponding changes in plant available water content, and could successfully be applied to assess the drought stress tolerance of new crop genotypes.

We found that changes in soil hydraulic properties caused by soil consolidation influenced the simulation results to high degree. The level of these changes was so high in the nonstressed treatments that we had to account for the seasonal variability of the soil hydraulic functions to calibrate the SWAP model against the TSW data, observed in the NS treatments. The Sobchuk-Walczak (SW) model could satisfactorily describe changes in soil hydraulic properties due to changes in soil bulk density. We could valuably improve the SWAP model performance when introducing temporally variable soil hydraulic properties in the model. Our results indicate that soil water balance studies should put more focus on the time variability of structure-dependent soil properties.

Acknowledgements. This study was supported by the Hungarian Scientific Research Fund (OTKA No. K101065 and K104816), by the TÁMOP project No. 422A-11/1/KONV-2012-0064 and by the bilateral agreement of the Slovak Academy of Sciences and the Hungarian Academy of Sciences (project number SNK5/2013) Eszter Tóth's research contributing to this publication was supported by the European Union and the State of Hungary, co-financed by the European Social Fund in the framework of TÁMOP 4.2.4. A/2-11-1-2012-0001 'National Excellence Program'.

\section{REFERENCES}

Bennett, S.J., Bishop, T.F.A., Vervoort, R.W., 2013. Using SWAP to quantify space and time related uncertainty in deep drainage model estimates: A case study from nothern NSW, Australia. Agricultural Water Management, 130, 142-153.

Boesten, J.J.T.I., Stroosnijder, L., 1986. Simple model for daily evaporation from fallow tilled soil under spring conditions in a temperate climate. Neth. J. Agric. Sci., 34, 75-90.

Cseuz, L., Pauk, J., Kertész, Z., Matuz, J., Fónad, P., Tari, I., Erdei, L., 2002. Wheat breeding for tolerance to drought stress at the Cereal Research Non-Profit Company. Acta Biologica Szegediensis, 46, 25-26.

Csorba, Sz., 2007. Studying the soil water regime of different wheat genotypes in a stress diagnosis system. Master thesis, Szent István University, Gödöllő, Hungary. (In Hungarian).

Deelstra, J., Farkas, Cs., Engebretsen, A., Kværnø, S., Beldring, S., Olszewska, A., Nesheim, L., 2010. Can we simulate runoff from agriculture-dominated watershed? Comparison 
of the DrainMod, SWAT, HBV, COUP and INCA models applied for the Skuterud catchment. In: Grzybek, A. (Ed.): Modelling of biomass utilisation for energy purpose. Bioforsk FOKUS, 5, 6, 119-128.

Djilianov, D., Georgieva, T., Moyankova, D., Atanassov, A., Shinozaki, K., Smeeken, S.C.M., Verma, D.P.S., Murata, N., 2005. Improved abiotic stress tolerance in plants by accumulation of osmoprotectants - gene transfer approach. Biotechnology \& Biotechnological Equipment, 19, 63-70.

Farkas, Cs., Gyuricza, Cs., László, P., Birkás, M., 2000. Study of the influence of soil tillage on soil water regime. In: Horn, R., van den Akker, J.J.H., Arvidsson, J. (Eds.): Subsoil Compaction. Advances in Geoecology, 32, Catena Verlag, Cremlingen Destedt, pp. 251-257.

Farkas, Cs., Hagyó, A., 2010. Applicability of profile- and watershed scale mathematical models for evaluating the environmental impacts of climate change. „Klíma-21” Füzetek, 62, 59-74. (In Hungarian).

Feddes, R.A., Kowalik, P.J., Zaradny, H., 1978. Simulation of field water use and crop yield. Centre for Agricultural Publishing and Documentation, Wageningen, The Netherlands, $195 \mathrm{p}$.

Fendeková, M., Fendek, M., 2012. Groundwater drought in the Nitra river basin - identification and classification. J. Hydrol. Hydromech., 60, 185-193.

Gáspár, L., Czövek, P., Fodor, F., Hoffmann, B., Nyitrai, P., Király, I., Sárvári, É., 2005. Greenhouse testing of wheat cultivators compared to those with known drought tolerance. Acta Biologica Szegediensis, 49, 97-98.

Głab, T. 2014. Effect of soil compaction and N fertilization on soil pore characteristics and physical quality of sandy loam soil under red clover/grass sward. Soil Till. Res., 144, 8-19.

Hermann, T., Makó, A., Máté, F., Tóth, G., Tóth, Z., 2006. Soil fertility assessment in a case study in Hungary. Cer Res Comm., 34,199-201.

IPCC, 2014: Climate Change 2014: Impacts, Adaptation, and Vulnerability. Part A: Global and Sectoral Aspects. Contribution of Working Group II to the Fifth Assessment Report of the Intergovernmental Panel on Climate Change [Field, C.B., V.R. Barros, D.J. Dokken, K.J. Mach, M.D. Mastrandrea, T.E. Bilir, M. Chatterjee, K.L. Ebi, Y.O. Estrada, R.C. Genova, B. Girma, E.S. Kissel, A.N. Levy, S. MacCracken, P.R. Mastrandrea, and L.L. White (eds.)]. Cambridge University Press, Cambridge, United Kingdom and New York, NY, USA, XXX pp.

Jirků, V., Kodešová, R., Nikodem, A., Mühlhanselová, M., Žigová, A., 2013. Temporal variability of structure and hydraulic properties of topsoil of three soil types. Geoderma, 204-205, 43-58.

Josa, R., Gorchis, G., Ginovart, M., Solé-Benet, A., 2013. Influence of tillage on soil macropore size, shape of top layer and crop development in a sub-humid environment. Biologia, 68, 1099-1103.

Lukács, A., Pártay, G., Németh, T., Csorba, Sz., Farkas, Cs., 2008. Drought stress tolerance of two wheat genotypes. Soil \& Water Res., 3, 95-104.

Kodešová, R., Jirků, V., Kodeš, V., Mühlhanselová, M., Nikodem, A., Žigová, A., 2011. Soil structure and soil hydraulic properties of Haplic Luvisol used as arable land and grassland. Soil Till. Res., 111, 154-161.

Korsunskaia, L.P., Farkas, Cs., 2004. Seasonal variability of soil water retention curves. In: Józefaciuk, G. (Ed.): Physics, chemistry and biogeochemistry in soil and plant studies. Multi-Authors Work, Institute of Agrophysics, Centre of Excellence for Applied Physics in Sustainable Agriculture
AGROPHYSICS, Lublin, Poland, pp. 78-82. Available at: http://www.ipan.lublin.pl/uploads/mat_coe/mat_coe13.pdf

Kutilek, M., Jendele, L., Panayiotopoulos, K.P., 2006. The influence of uniaxial compression upon pore size distribution in bi-modal soils. Soil Till. Res., 86, 27-37.

Ma, Y., Feng, S., Huo, Z., Song X., 2011. Application of the SWAP model to simulate the field water cycle under deficit irrigation in Beijing, China. Mathematical and Computer Modelling, 54, 1044-1052.

Maracchi, G., Sirotenko, O., Bindi, M., 2005. Impacts of present and future climate variability on agriculture and forestry int he temperate regions: Europe. Incrasing Climate Variability and Change, 70, 117-135.

Monteith, J.L., 1981. Evaporation and surface temperature. Quarterly J. Royal Soc., 107, 1-27.

Moriasi, D. N., Arnold, J.G., van Liew, M.W., Bingner, R.L., Harmel, R.D., Veith, T.L., 2007. Model evaluation guidelines for systematic quantification of accuracy in watershed simulations, Transactions of the ASABE 50, 885900. Available at:

http://swat.tamu.edu/media/1312/moriasimodeleval.pdf

Mualem, Y. 1976. A new model for predicting the hydraulic conductivity of unsaturated porous media. Water Resources Research, 12, 513-522.

Mubarak, I., Mailhol, J.C., Angulo-Jaramillo, R., Bouarfa, S., Ruelle, P., 2009. Effect of temporal variability in soil hydraulic properties on simulated water transfer under highfrequency drip irrigation. Agricultural Water Management, 96, 1547-1559.

Nash, J.E., Sutcliffe, J.V., 1970. River flow forecasting through conceptual models part I - A discussion of principles. Journal of Hydrology, 10, 3, 282-290.

Pant, J., Berkasem, B., Noppakoonwong, R., 1998. Effect of water stress ont he boron response of wheat genotypes under low boron conditions. Plant and Soil, 202, 193-200.

Querrie, S.A., Stojanovic, J., Pekic, S., 1999. Improving drought resistance in small-grained cereals: A case study, progress and prospects. Plant Growth Regulation, 29, 1-21.

Richards, L.E., 1931. Capillary conduction of liquids through porous mediums. Phys., 1, 318-339.

Rosenzweig, C., Iglesias, A., Yang, X.B., Epstein, P.R., Chivian, E., 2001. Climate change and extreme weather events. Implications for food production, plant diseases, and pests. Global Change \& Human Health, 2, 90-104.

Schwen, A., Bodner, G., Loiskandl, W., 2011. Time-variable soil hydraulic properties in near-surface soil water simulations for different tillage methods. Agricultural Water Management, 99, 42-50.

Sobczuk, A., Walczak, R.T., 1996. Bulk density dependence parametrization of water potential - moisture characteristics of soil. Polish Journal of Soil Science, XXIX/2, 81-85.

Soldevilla-Martinez, M., Quemada, M., López-Urrea, R., Munoz-Carpena, R., Lizaso, J.I., 2014. Soil water balance: Comparing two simulation models of different levels of complexity with lysimeter observations. Agricultural Water Management, 139, 53-63.

Szász, G., 1997. The agrometeorology of agricultural water management. In: Szász, G., Tőkei, L., (Eds): Meteorology for Agricultural Engineers, Horticulturalists and Foresters. Mezőgazda Publisher, Budapest, 411-470. (In Hungarian).

Trakal, L., Kodesová, R., Komárek, M., 2013. Modelling of Cd, $\mathrm{Cu}, \mathrm{Pb}$ and $\mathrm{Zn}$ transport in metal contaminated soil and their uptake by willow (Salix x smithinana) using HYDRUS-2D program. Plant Soil, 366, 433-451. 
van Dam, J.C., 2000. Field-scale water flow and solute transport. SWAP model concepts, parameter estimation and case studies. Doctoral Thesis Wageningen University. ISBN 90-5808-256-3

van Dam, J.C., Groenendijk, P., Hendriks, R.F.A., Kroes, J.G., 2008. Advances of modeling water flow in variably saturated soils with SWAP. Vadose Zone J., 7, 2, 640-653.

van Genuchten, M.Th., 1980. A closed-form equation for predicting the hydraulic conductivity of unsaturated soils. Soil Sci. Soc. Am. J., 44, 892-898.

van Genuchten, M.Th., Leij, F.J., Yates, S.R., 1991. The RETC code for quantifying the hydraulic functions of unsaturated soils, version 1.0. EPA Report 600/2-91/065, U.S. Salinity Laboratory, USDA, ARS, Riverside, California.
Várallyay, Gy., 2005. Life quality - soil - food chain. Cer. Res. Comm., 34, 5-8.

Végh, K.R., 2013. Root and leaf traits, water use and drought tolerance of maize genotypes. Biologia, 68, 1123-1127.

WRB, 2006. World reference base for soil resources 2006. 2nd edition. World Soil Resources Reports No. 103. FAO, Rome. $128 \mathrm{pp}$.

Zhang, S., Grip, H., Lovdahl, L., 2006. Effect of soil compaction on hydraulic properties of two loess soils in China. Soil Till. Res., 90, 117-125.

Zhou, X., Lin, H.S., White, E.A., 2008. Surface soil hydraulic properties in four soil series under different land uses and their temporal changes. Catena, 73, 180-188.

Received 12 June 2014

Accepted 1 September 2014

Note: Colour version of Figures can be found in the web version of this article. 